\title{
Effects of Tour Guides Training on Their Performance in Kenya
}

\author{
Francis Kabii \\ Kenya Utalii College, Nairobi, Kenya \\ Moses Makonjio Okello, Nehemiah Kipruto \\ Moi University, Eldoret, Kenya
}

\begin{abstract}
It is important for a completive tourism destination to ensure that tourists get the company of a professional tour guide who guides and interprets attraction in the areas visited. Undefined level of education, lack of standardized training curriculum, and lack of barrier to the guiding career have affected the performance of tour guides in Kenya. Limited research in Kenya has been conducted to establish the role of guides in satisfying customer and protecting the environment. The study objective was to examine tour guides' interpretation knowledge and their opinion on areas that require more training so as to improve their performance. The study hypothesized that tour guides' opinions on their training needs are independent on the level of education, work experience and qualification. It is hypothesized that guides require additional training in flora and fauna of East Africa, cultural heritage and customer service. They require training in ICT (Information Communications Technology), eco-tourism principles, and at least one foreign language. The study hypothesizes that the higher the level of a guide's training, the more resourceful the guide will be. The study used qualitative and quantitative research approaches where questionnaires, interviews and focus groups discussion (FGDs) were used to collect the primary data. The finding shows that tour guides' opinions on areas they require further training were independent of their highest level of education, work experience and qualification. Most guides irrespective of their level of education, work experience and qualifications were of the opinion that they needed more training on mammals and plants $\left(\chi^{2}=1.07, \mathrm{df}=2, P=0.583\right)$, training on birds and insects $\left(\chi^{2}=0.254, \mathrm{df}=2, P=0.885\right)$ and training on culture and history of East Africa $\left(\chi^{2}=1.140, \mathrm{df}=2, P=0.566\right)$. Respondents' training needs were independent on the duration of tour guiding course training had taken. Guides trained for less than six months, one year and more than two years agreed that training on foreign language $\left(\chi^{2}=4.84, \mathrm{df}=2, P=0.196\right)$, ecotourism principles $\left(\chi^{2}=1.62, \mathrm{df}=2, P=0.653\right)$ and tour planning and costing $\left(\chi^{2}=399, \mathrm{df}=3, P=0.262\right)$ would improve their performance. The study concludes that tour guides are aware of the areas that they need to be trained and should be consulted before organizing such training. They require more training irrespective of their level of education, certification and work experience. The study recommends tour guide curriculum be standardized and all guides should sit for an exam before they are licensed to guide and only those with such license be allowed to practice guiding.
\end{abstract}

Keywords: tour guide training, effects, performance, product knowledge

Francis Kabii, Lecturer, Tourism Department, Kenya Utalii College. Email: fkabii@yahoo.com. Moses Makonjio Okello, Professor of Tourism and Wildlife Management, Moi University. Nehemiah Kipruto, Lecturer, Tourism Department, Moi University. 


\section{Introduction}

Tour guides are forgotten employees within the services provision chain in tourism. In Kenya, most of them work for less than six months in a year. Their services are only required during the high seasons, meaning that during the low season they are jobless and must look for alternative sources of income. Most guides are employed on contract with a big number being self-employed. They are poorly motivated and have low salaries yet they are expected to offer quality service to the visitors. Unlike other studies which have explored factors that affect employees who are in permanent employment, this study revolves around guides, most of whom are under contract. This is what makes the study unique.

This paper investigates factors that influence tour guides' opinions on the areas they desire more training and how such training affects their performance. The objective of this study was to examine the effects of education level, work experience and qualification on guides' training needs and performance.

Although several studies have reported the factors that affect guide's performance in other parts of the world, no studies have been conducted in Africa and Kenya for this case. This is the gap the study intends to fill. Tourism remains a major foreign exchange earner for most countries in Sub-Saharan Africa and the role of guides is vital and can therefore not be ignored. A well-trained guide is an asset to the company, destination and to the visitor. The paper hypothesizes that the education, work experience and the qualification of guides influence the areas they would like to be trained in order to improve their performance.

Their expertise and performance influence visitors to come to Kenya for a return visit. Guides are part of the tourism product and determine the competitiveness of the destination. They stay and interact with the visitors the longest as compared to other individuals in the service chain. They are the link between the visitors, the host communities and the tour company. Their services are produced and consumed by the visitors at the same time. They are marketers and promoters of the product through interaction with the visitors.

Tour guide career in Kenya faces many challenges. At the recruitment level, their qualification requirements are not uniform since there are no agreed qualification criteria or standardization in their training and certification. Most guides do not have formal training while those who are trained have gone through different curricula. No academic qualification is required for one to be contracted as a guide meaning that anybody can be engaged as a guide mostly during the high season when demand is higher than supply. This is dangerous for the tourism industry and the destination bearing in mind the important roles and duties that are expected of the guides. It would, therefore, be important for any destination to invest heavily in guides training. To organize for such training, it would be important to do the training need assessment in order to hear from the guide's areas they believe they need training. Guides should be involved in curriculum development and delivery.

\section{Study Objective and Hypothesis}

The purpose of this study was to examine factors that affect tour guides' opinions on areas they require training in order to improve their performance. The study further investigated whether there was any relationship between their training needs and their level of education, professional qualification and work experience. Statistical hypothesis assumed that:

Ho: Tour guides' opinion on areas they require more training in order to improve their performance is independent on their: (1) level of education; (2) professional qualification; and (3) work experience.

$\mathrm{H}_{1}$ : Tour guides' opinion on areas they require more training in order to improve their performance is dependent on: (1) level of education; (2) professional qualifications; and (3) work experience. 
The study hypothesizes that tour guide education level, work experience and professional qualification influenced their opinion on their training needs. Guides require additional training in flora and fauna of East Africa, cultural heritage and customer service. They require training in ICT, eco-tourism principles, and at least one foreign language. They also need leadership and communication skills, presentation skills and vehicle maintenance skills. The study hypothesizes that the higher the educational level of a guide's training, the more resourceful the guide will be. Tour guides have not been equipped with enough skills, knowledge and other attributes that may be required to satisfy customers. It is hypothesized that poor training of guides affects their performance. There should be some tailor-made training programs for all guides irrespective of their terms of employment, age and work experience. Such training should be mandatory for one to be qualified and licensed as a practicing guide.

\section{Literature Review}

The term tour guide (TG) is familiar to anybody who visits a destination for holiday. Tour guides have responsibilities and duties that are intended to satisfy visitors. The Oxford Dictionary (Stevenson, 2010) defined a tour guide as "a person who shows other people the way to places especially somebody employed to show tourists interesting places". Due to multifaceted nature of tour guides, European Federation of Tour Guides Association (EFTGA) and International Association of Tour Managers (IATM) have defined a tour guide as "a person who interprets in an inspiring and entertaining manner in the language of visitors choice, the culture, natural heritage and the environment of a destination".

It is from these definitions that most scholars define the roles of tour guides (Weiler \& Ham, 2001; Wang, Hsieh, \& Huan, 2000; Ap \& Wong, 2001; Michie, 2004).

The importance of tour guides can be seen from the way it has gained attention from scholars from different regions: Botswana (Gurung, Simmons, \& Devlin, 1996), Indonesia (Cole, 1997; Dahles, 2002), Madagascar (Ormsby \& Mannle, 2006), Thailand (Cohen, 1982; Hounnaklang, 2004), Australia (Ballantyne \& Hughes, 2001; Hillman, 2004; Howard, Thwaites, \& Smith, 2001; Yu \& Weiler, 2001), Canada (Randall \& Rollins, 2009), Greece (Skanavis \& Giannoulis, 2010), Hong Kong (Ap \& Wong, 2001; Mak, Wong, \& Chang, 2011), the United Kingdom (Hounnaklang, 2004) and the United States (Ham \& Weiler, 2003).

Weiler and Black (2015) noted that collectively, these studies have produced important findings of the roles of guides that seem particularly relevant to developing countries. Guiding in these countries is a means of livelihood that helps to reduce poverty (Weiler \& Black, 2015). Pereira and Mykletun (2012) identified contribution to the economic sustainability of a destination or region as a key sphere of a guide's role. Weiler and Black (2015) indicated that when earning a living is a priority, there may be less attention to the destination/resource management sphere.

Destinations offering guided tours place heavy emphasis on customer satisfaction. The responsibility of achieving customer satisfaction is delegated to tour guide who throughout the entire duration is in a continuous and intense contact with the tour participants (Geva \& Goldman, 1991). The underlying belief behind this is that satisfaction from guides performance translates to an enhanced image of the tour company and then to repeat purchase. 
Tour guiding duties constitute a strategic factor in the representation of a destination area and in influencing the quality of the tourist experience, the length of stay, and the resulting economic benefits for a local community (Dahles, 2002). Guides are portrayed as people who build bridges among different groups of people through the deployment of money, services, access, and information (Gurung et al., 1996).

Tour guides are key front line players in the tourism industry (Wong, 2001). They represent the company and the destination visited. They make visitors dream come true. The role of a tour guide as an educator has been highlighted by Holloway (1981) and Pond (1993). The responsibility for achieving tourist satisfaction is mostly entrusted in guides who are in position to customize the tours quality to individual needs and preference (Geva \& Goldman, 1991).

\section{Guides Training as a Factor That Influences Performance}

Training has been identified as a major factor influencing employees performance by Guest (1997), Swart, Mann, Brown, and Price (2005), Armstrong (2009), and Beardwell, Holden, and Claydon (2004). Other factors that affect employee's performance have been identified as: (1) working condition (Newstrom \& Davis, 2002); (2) employees' reward system (Armstrong, 2009); (3) employees' well-being (Nielsen, 2002); and (4) employees' team work (Pigors \& Myers, 1989).

Specifically, training has been identified as an important quality assurance measure, and is widely recognized as a critical means to enhance the service standard of the guiding profession (Mak et al., 2011; Ap \& Wong, 2001; Ballantyne \& Hughes, 2001; Black \& Ham, 2005; Black, Ham, \& Weiler, 2001; Dioko \& Unakul, 2005; McDonnell, 2001; Weiler \& Ham, 2002). Specialized training is particularly essential as tour guides need to perform many important roles (Black et al., 2001). Well-trained and qualified tour guides enhance customer satisfaction and image of the destination visited (Dioko \& Unakul, 2005). In addition to formal and structured training, Lugosi and Bray (2008) emphasized that destination culture is essential in facilitating informal learning and development of tour guides, particularly in the forms of social learning and experiential learning.

In their study on guides, Mak et al. (2011) highlighted problems and issues associated with untrained guides. Lack of formal training does not only affect the guides esteem but also affect the quality of services visitors receive. Likewise, lack of training can result in unethical guiding practices, poor guide performance, and negative publicity towards the guiding profession, damage to the destination's image (Ap \& Wong, 2001; Mak et al., 2011; Ballantyne, Packer, \& Hughes, 2009) and the quality of visitors' experience and level of satisfaction. Studies conducted by Kong, Cheung, and Baum (2009) and Pond (1993) also found that guides have identified that lack of training can affect their esteem, recognition of the career like other professionals, lack of rewards and incentives from employers.

Literature from different scholars show that the desire for training may come from guides themselves, professional tour guide associations, tour operators, government agencies and the tourism industry (Ap \& Wong, 2001; Mak et al., 2011). Their findings indicate that training is an important means of improving guiding standards and professionalism. To be effective, training needs to be adequate, appropriate and consistent, encourage collaboration between industry and educational institutions. It is with this background in mind that this paper investigates factors that influence guides' training needs. 


\section{Research Methodology}

The study was explanatory in nature and examined factors that affect guides performance. A combination of qualitative and quantitative research approaches was used which allowed the researchers to collect and analyze data. The study areas were Nairobi City market car park area, Masai Mara national reserve, Tsavo Wes national park, Shimba Hills national park, Arabuko Sokoke forest, Kakamega forest and Amboseli National park. Most of the data were collected during the high season (August 2016 and April 2017) when most tourists visit Masai Mara National Park to watch the wildebeest migration.

Cluster sampling was used so that guides from different locations would be involved. The first cluster was the savannah targeting guides visiting Maasai Mara region, Amboseli national park and Tsavo west region. The second cluster targeted guides in the forest region of Kakamega forest, Arabuko Sokoke forest and Shimba Hill national reserve. The third cluster targeted town or city guides in Nairobi CBD and coastal town (Mombasa, Malindi and Watamu).

A total of 310 questionnaires were distributed where 250 were completed and returned. Likewise, there were four focus group discussions (FGDs) which involved a total of 100 respondents. In total, 350 respondents participated in the study.

\section{Results and Hypothesis Testing}

Tour guides' responses were subjected to chi-square goodness of fit to determine whether observed frequency of an group of respondents attributes was by chance and whether it was significant at $P$-value $=0.05$. On gender, the majority of the guides were males $\left(95 \% ; \chi^{2}=178.57, \mathrm{df}=1, P<0.001\right)$. Minority (13\%) of them were single as compared to the majority $(87 \%)$ who are married $\left(\chi^{2}=317.88, \mathrm{df}=2, P<0.001\right)$. On their education level, the majority (77\%) of the respondents had secondary schools certificate as the highest level of education as compared to only $16 \%$ of the respondents who had university as the highest level of education $\left(\chi^{2}=189.83, \mathrm{df}=2, P<0.001\right)$. In relation to their terms of employment, the majority of tour guides $(62 \%)$ were either on contract or self-employed as compared to only $38 \%$ who are in permanent employment $\left(\chi^{2}=4.54, \mathrm{df}=3, P<0.001\right)$. More than $80 \%$ earn less than KES 40,000 with only $13 \%$ earning over KES 40,000 . In relation to the mode of training, $40 \%$ of the respondents had informal job training as compared to $55 \%$ who were trained formally. They had been awarded either a certificate or a diploma in tour guiding. Likewise only $18 \%$ had a degree but not in tour guiding. On work experience, $13 \%$ had less than five years of experience while the majority had worked for 10 years. Twenty three percent had more than 15 years of experience and this finding was significant at $\chi^{2}=31.48, \mathrm{df}=3, P<0.001$. The summary of the respondent's profile is given in Table 1 below.

Table 1

Summary of Respondent's Profile

\begin{tabular}{llcl}
\hline & Attribute & Frequency (\%) & $\begin{array}{l}\text { Chi-square goodness of fit, df, } \\
\text { and } P \text {-value }\end{array}$ \\
\hline \multirow{2}{*}{ Gender } & Male & $\begin{array}{c}212(95 \%) \\
12(5 \%)\end{array}$ & $\chi^{2}=178.57, \mathrm{df}=1, P<0.001$ \\
\hline \multirow{2}{*}{ Marital status } & Female & $\begin{array}{c}212(87 \%) \\
32(13 \%)\end{array}$ & $\chi^{2}=317.88, \mathrm{df}=2, P<0.001$ \\
\hline
\end{tabular}


(Table 1 continued)

\begin{tabular}{|c|c|c|c|}
\hline & Attribute & Frequency $(\%)$ & $\begin{array}{l}\text { Chi-square goodness of fit, } \mathrm{df} \text {, } \\
\text { and } P \text {-value }\end{array}$ \\
\hline \multirow{3}{*}{ Highest level of education } & Primary & $16(7 \%)$ & \multirow{3}{*}{$\chi^{2}=189.83, \mathrm{df}=2, P<0.001$} \\
\hline & Secondary & $168(77 \%)$ & \\
\hline & University & $34(16 \%)$ & \\
\hline \multirow{3}{*}{ Professional qualification } & Certificate & $117(56 \%)$ & \multirow{3}{*}{$\chi^{2}=94.17, \mathrm{df}=3, P<0.001$} \\
\hline & Diploma & $86(41 \%)$ & \\
\hline & Degree & $6(3 \%)$ & \\
\hline \multirow{4}{*}{ Mode of respondents training } & On job & $91(40 \%)$ & \multirow{4}{*}{$\chi^{2}=200.72, \mathrm{df}=3, P<0.001$} \\
\hline & College & $125(56 \%)$ & \\
\hline & University & $4(2 \%)$ & \\
\hline & Others & $5(2 \%)$ & \\
\hline \multirow{4}{*}{ Terms of employment } & Self-employment & $36(16 \%)$ & \multirow{4}{*}{$\chi^{2}=4.54, \mathrm{df}=3, P<0.001$} \\
\hline & Permanent & $86(38 \%)$ & \\
\hline & Contract & $56(25 \%)$ & \\
\hline & Free lance & $47(21 \%)$ & \\
\hline \multirow{4}{*}{ Tour guiding experience } & Less than 5 years & $12.4(13 \%)$ & \multirow{4}{*}{$\chi^{2}=31.48, \mathrm{df}=3, P<0.001$} \\
\hline & $5-10$ years & $36.8(38 \%)$ & \\
\hline & $10-15$ years & $26(27 \%)$ & \\
\hline & Over 15 years & $22(23 \%)$ & \\
\hline \multirow{4}{*}{ Salary and benefits in Kenya shillings per month } & Less than 20,000 & $32(38 \%)$ & \multirow{4}{*}{$\chi^{2}=126.64, \mathrm{df}=3, P<0.001$} \\
\hline & $21,000-40,000$ & $42(50 \%)$ & \\
\hline & $40,000-60,000$ & $10(11 \%)$ & \\
\hline & Over 60,000 & $2(2 \%)$ & \\
\hline
\end{tabular}

\section{Findings of Hypothesis 1 (H1)}

The hypothesis sought to find out if tour guides' opinions on the areas they require training were dependent or independent on their highest level of education. The three levels of tour guide education considered in these cases were primary, secondary and university levels.

$\mathrm{H} 1$ : $\mathrm{H}_{0}$ : Tour guides' opinion on areas tour guides requires more training in order to improve their performance is independent on their level of education.

$\mathrm{H}_{1}$ : Tour guides' opinion on areas they require more training in order to improve their performance is dependent on their level of education.

Respondents were asked to tick yes or no on some selected areas and give their opinion on whether training in those areas would enhance their performance. These areas had been suggested in previous FGDs as some of the areas where the guides felt that they were weak. They had the opinion that if trained in the areas that had been proposed in FGDs, they would be more knowledgeable and this would boost their performance when interacted with customers. The question was: which of the following areas do you feel you require more training in order to perform better as a guide? The findings are given in Table 2.

The guide's responses were subjected to Pearson's Chi-square $t$-test to measure any relationship or association. If $P$-value was equal or less than 0.05 , then the response was considered dependent on the attribute and independent of the attribute if $P$-value was greater than 0.05 . 
Table 2

Response of Tour Guides on Whether Training Them in the Areas Outlined Was Independent on Their Level of Education

\begin{tabular}{|c|c|c|c|c|}
\hline \multirow{2}{*}{$\begin{array}{l}\text { Would training in the areas listed below enhance your } \\
\text { performance as a guide? }\end{array}$} & \multicolumn{2}{|c|}{ Response } & \multirow{2}{*}{ Education level } & \multirow{2}{*}{$\begin{array}{l}\text { Chi-square cross tabulations, } \\
\text { df, and } P \text {-value }\end{array}$} \\
\hline & Yes & No & & \\
\hline \multirow{3}{*}{ Mammals and plants of East Africa } & $13(93 \%)$ & $1(7 \%)$ & Primary & \multirow{3}{*}{$\chi^{2}=1.07, \mathrm{df}=2, P=0.583$} \\
\hline & $133(84 \%)$ & $24(16 \%)$ & Secondary & \\
\hline & $24(89 \%)$ & $3(11 \%)$ & University & \\
\hline \multirow{3}{*}{ Birds and insects of East Africa } & $14(94 \%)$ & $1(6 \%)$ & Primary & \multirow{3}{*}{$\chi^{2}=0.24, \mathrm{df}=2, P=0.885$} \\
\hline & $146(91 \%)$ & $14(9 \%)$ & Secondary & \\
\hline & $29(94 \%)$ & $20(6 \%)$ & University & \\
\hline \multirow{3}{*}{ Tour planning and costing } & $10(77 \%)$ & $3(23 \%)$ & Primary & \multirow{3}{*}{$\chi^{2}=3.79, \mathrm{df}=2, P=0.150$} \\
\hline & $111(69 \%)$ & $50(31 \%)$ & Secondary & \\
\hline & $25(86 \%)$ & $4(14 \%)$ & University & \\
\hline \multirow{3}{*}{ Culture and history } & $13(83 \%)$ & $1(17 \%)$ & Primary & \multirow{3}{*}{$\chi^{2}=1.14, \mathrm{df}=2, P=0.566$} \\
\hline & $12(82 \%)$ & $29(18 \%)$ & Secondary & \\
\hline & $23(82 \%)$ & $5(18 \%)$ & University & \\
\hline \multirow{3}{*}{ Customers service and communications skills } & $12(85 \%)$ & $2(15 \%)$ & Primary & \multirow{3}{*}{$\chi^{2}=0.45, \mathrm{df}=2, P=0.798$} \\
\hline & $136(85 \%)$ & $24(15 \%)$ & Secondary & \\
\hline & $26(90 \%)$ & $3(10 \%)$ & University & \\
\hline \multirow{3}{*}{ Reptiles and marine ecology } & $75(77 \%)$ & $14(15 \%)$ & Primary & \multirow{3}{*}{$\chi^{2}=1.33, \mathrm{df}=2, P=0.512$} \\
\hline & $102(88 \%)$ & $13(12 \%)$ & Secondary & \\
\hline & $4(85 \%)$ & $1(15 \%)$ & University & \\
\hline \multirow{3}{*}{ Computer skills } & $62(86 \%)$ & $24(14 \%)$ & Primary & \multirow{3}{*}{$\chi^{2}=1.84, \mathrm{df}=2, P=0.397$} \\
\hline & $85(72 \%)$ & $29(28 \%)$ & Secondary & \\
\hline & $4(80 \%)$ & $1(20 \%)$ & University & \\
\hline \multirow{3}{*}{ Eco-tourism } & $71(86 \%)$ & $13(14 \%)$ & Primary & \multirow{3}{*}{$\chi^{2}=0.130, \mathrm{df}=2, P=2.930$} \\
\hline & $97(85 \%)$ & $20(15 \%)$ & Secondary & \\
\hline & $3(83 \%)$ & $1(17 \%)$ & University & \\
\hline \multirow{3}{*}{ Foreign language } & $79(91 \%)$ & $7(9 \%)$ & Primary & \multirow{3}{*}{$\chi^{2}=2.18, \mathrm{df}=2, P=0.335$} \\
\hline & $105(90 \%)$ & $10(10 \%)$ & Secondary & \\
\hline & $3(94 \%)$ & $1(6 \%)$ & University & \\
\hline
\end{tabular}

Training on mammals and plants. The level of tour guide education did not influence their opinion that training in mammals and plants of East Africa could enhance their performance. From the findings of Table 2, we note that there is no significant relationship between guide's level of education and desire for more training on mammals and plants of East Africa or any other area. All guides irrespective of their level of training are required to be trained in this area. The test statistics was $\chi^{2}=1.07, \mathrm{df}=2, P=0.583$.

Training on birdlife and insects of East Africa. Likewise, the respondents were asked whether training on birdlife and insects of East Africa would make them perform better. Ninety four percent of guides with the highest level of training being primary school level agreed with the statement as compared with $94 \%$ of those with the highest level of education being university level. In general, 92\% of all respondents irrespective of their level of education said that they needed training on birdlife and insects and such training would improve their performance $\left(\chi^{2}=0.245, \mathrm{df}=2, P=0.885\right.$; see Table 2$)$. 
Training on tour planning and costing. The same question was asked but this time the training need was in tour planning and costing. Many tour guides have not been trained on tour planning and costing and it was the researchers' opinion that such training would help them appreciate the process of tour planning and improve their performance. A majority of $86 \%$ university graduates needed to be trained as compared to $69 \%$ who had secondary school as the highest level of education. In total, $72 \%$ of total respondents agreed that training in tour planning and costing would improve their performance. We note that there was a weak relationship between the level of education and their opinion $\left(\chi^{2}=3.798, \mathrm{df}=2, P=0.150\right)$.

Culture and history of East Africa. A majority (83\%) of the respondents with the primary school as the highest level of education indicated that training on culture and history would improve their performance. We also find that $82 \%$ of the respondents with secondary and university as the highest level of education indicated that they also needed such training $\left(\chi^{2}=1.14, \mathrm{df}=2, P=0.566\right)$.

Summary of H1. It can be seen from Table 2 that all respondents needed training on customer service and communication skills, computer knowledge, reptiles, eco-tourism and foreign language.

Tour guides opinion on whether training would enhance their performance was independent on their level of education. From the findings, we can therefore conclude that there is no significant relationship between the level of training primary secondary and even degree level. All guides irrespective of their training said that they needed more training in all of the selected areas. Such training was likely to increase their confidence when guiding and by extension improve their performance.

\section{Findings of the Second Hypothesis (H2)}

The hypothesis sought to find whether tour guides' opinions on the areas they require training were dependent or independent on their professional qualification. The levels of qualifications considered in these cases were three: certificate, diploma and degree holders.

H2: Ho: Tour guides' opinion on areas they require more training in order to improve their performance is independent on their level of their professional qualification.

$\mathrm{H}_{1}$ : Tour guides' opinion on areas they require more training in order to improve their performance is dependent on their level of their professional qualification.

From a total of 191 respondents who agreed that such training was important, 90\% (97) were certificate holders, $79 \%$ diploma holders and $100 \%$ degree holders. A total of $31 \%$ respondents disagreed. Amongst them were 11 certificate holders and 1 diploma holder. The finding was not significant $\left(\chi^{2}=5.143, \mathrm{df}=2, P=0.076\right)$ as given in Table 3. Respondents were asked whether training on birds and insects would improve their performance, a majority of 215 agreed. From this majority, 92\% (102) were certificate holders as compared to 94\% diploma and $100 \%$ degree holders respectively. The finding was not significant $\chi^{2}=0.596$, $\mathrm{df}=2$, $P=0.742$.

In summary, it can be observed that the qualification of guides did not influence their opinion on training on tour planning $\left(\chi^{2}=0.202, \mathrm{df}=2, P=0.904\right)$, training on customer care and communication skills $\left(\chi^{2}=4.639\right.$, $\mathrm{df}=2, P=0.098)$ and foreign language $\left(\chi^{2}=2.127, \mathrm{df}=2, P=0.345\right)$. Guides irrespective of their professional qualification were of the opinion that they required training in those areas in order to improve their performance. 
Table 3

Findings on the Relationships Between Level of Respondent's Qualification and Their Training Needs

\begin{tabular}{|c|c|c|c|c|}
\hline \multirow{2}{*}{ Information sought from respondents } & \multirow{2}{*}{$\begin{array}{l}\text { Respondents' } \\
\text { qualifications }\end{array}$} & \multicolumn{2}{|c|}{ Response $(N=250)$} & \multirow{2}{*}{$\begin{array}{l}\text { Chi-square cross tabulations } \\
\text { df, and } P \text {-value }\end{array}$} \\
\hline & & Yes & No & \\
\hline \multirow{3}{*}{$\begin{array}{l}\text { Would you need training in mammals and plants } \\
\text { to enhance your performance }\end{array}$} & Certificate & $97(90 \%)$ & $10 \%$ & \multirow{3}{*}{$\chi^{2}=5.143, \mathrm{df}=2, P=0.076$} \\
\hline & Diploma & $59(79 \%)$ & $21 \%$ & \\
\hline & Degree & $4(100 \%)$ & 0 & \\
\hline \multirow{3}{*}{$\begin{array}{l}\text { Would you need training in birds and insects to } \\
\text { enhance your performance }\end{array}$} & Certificate & $102(92 \%)$ & $18 \%$ & \multirow{3}{*}{$\chi^{2}=0.596, \mathrm{df}=2, P=0.742$} \\
\hline & Diploma & $74(94 \%)$ & $16 \%$ & \\
\hline & Degree & $5(100 \%)$ & 0 & \\
\hline \multirow{3}{*}{$\begin{array}{l}\text { Would you need training in tour planning and } \\
\text { costing to enhance your performance }\end{array}$} & Certificate & $78(71 \%)$ & $29 \%$ & \multirow{3}{*}{$\chi^{2}=0.202, \mathrm{df}=2, P=0.904$} \\
\hline & Diploma & $59(74 \%)$ & $26 \%$ & \\
\hline & Degree & $3(75 \%)$ & $25 \%$ & \\
\hline \multirow{3}{*}{$\begin{array}{l}\text { Would you need training in culture and history to } \\
\text { enhance your performance }\end{array}$} & Certificate & $90(85 \%)$ & $15 \%$ & \multirow{3}{*}{$\chi^{2}=1.308, \mathrm{df}=2, P=0.520$} \\
\hline & Diploma & $61(81 \%)$ & $19 \%$ & \\
\hline & Degree & $4(100 \%)$ & 0 & \\
\hline \multirow{3}{*}{$\begin{array}{l}\text { Would you need training in customers service and } \\
\text { communications skills to enhance your } \\
\text { performance }\end{array}$} & Certificate & $98(90 \%)$ & $2 \%$ & \multirow{3}{*}{$\chi^{2}=4.639, \mathrm{df}=2, P=0.098$} \\
\hline & Diploma & $62(80 \%)$ & $20 \%$ & \\
\hline & Degree & $4(100 \%)$ & 0 & \\
\hline \multirow{3}{*}{$\begin{array}{l}\text { Would you need training in reptiles and marine } \\
\text { ecology to enhance your performance }\end{array}$} & Certificate & $93(86 \%)$ & $14 \%$ & \multirow{3}{*}{$\chi^{2}=1.805, \mathrm{df}=2, P=0.400$} \\
\hline & Diploma & $72(90 \%)$ & $10 \%$ & \\
\hline & Degree & $6(100 \%)$ & 0 & \\
\hline \multirow{3}{*}{$\begin{array}{l}\text { Would you need training in computer skills to } \\
\text { enhance your performance }\end{array}$} & Certificate & $81(76 \%)$ & $24 \%$ & \multirow{3}{*}{$\chi^{2}=0.876, \mathrm{df}=2, P=0.645$} \\
\hline & Diploma & $56(70 \%)$ & $30 \%$ & \\
\hline & Degree & $4(80 \%)$ & $20 \%$ & \\
\hline \multirow{3}{*}{$\begin{array}{l}\text { Would you need training in eco-tourism to } \\
\text { enhance your performance }\end{array}$} & Certificate & $94(87 \%)$ & $13 \%$ & \multirow{3}{*}{$\chi^{2}=1.301, \mathrm{df}=2, P=0.522$} \\
\hline & Diploma & $66(84 \%)$ & $16 \%$ & \\
\hline & Degree & $5(100 \%)$ & 0 & \\
\hline \multirow{3}{*}{$\begin{array}{l}\text { Would you need training in foreign language to } \\
\text { enhance your performance }\end{array}$} & Certificate & $93(87 \%)$ & $13 \%$ & \multirow{3}{*}{$\chi^{2}=2.127, \mathrm{df}=2, P=0.345$} \\
\hline & Diploma & $74(93 \%)$ & $17 \%$ & \\
\hline & Degree & $5(100 \%)$ & 0 & \\
\hline
\end{tabular}

Summary of H2. The level of professional qualification did not influence the guides on their opinion on the areas they desired more training. There was a minimal difference in their opinions.

From these findings, the study therefore failed to reject the null hypothesis that suggested tour guides' opinions on training needs are independent on their level of professional qualification. However, this finding was not significant at $P=0.05$ which made us conclude that tour guide's training need is not dependent on their professional qualification.

\section{Findings of the Third Hypothesis (H3)}

The hypothesis sought to find out whether tour guides' opinions on the areas they require training were dependent or independent on how respondents were trained. Some guides were trained through formal training in colleges and universities while others were trained on the job.

The study found out that method in which guides are trained had minimal influence on their response to their training needs. Training need is independent in their form of training.

H3: Ho: Tour guides' opinion on areas they require more training in order to improve their performance is independent on how a guide was trained (on the job, formal and informal). 
$\mathrm{H}_{1}$ : Tour guides' opinion on areas they require more training in order to improve their performance is dependent on how a guide was trained (on the job, formal and informal).

The finding indicated that there is no much difference in the level of agreements on whether training on mammals and plants will improve their performance or not. Eighty-six percent of those trained on the job agreed with the statement as compared to $83 \%$ and $100 \%$ of those trained in colleges and university respectively (see Table 4). From 250 respondents who responded to the question, 73 were trained on the job, 92 through training colleges with only three at degree level. Ninety four percent of those trained on the job said training on birds and insect would make them perform better as compared to $93 \%$ (college) and $100 \%$ university graduates. In general, $76 \%$ of the total respondents agreed that such training is important while the minority $23 \%$ did not think it would affect their performance $\left(\chi^{2}=1.145, \mathrm{df}=3, P=0.766\right.$ ).

Likewise, respondents were asked to state whether they needed to be trained on tour planning and costing to improve their performance. Table 4 shows $73 \%$ of those trained on job said yes as opposed to $77 \%$ (college) and $100 \%$ (those trained in the university) with $\chi^{2}=6.767, \mathrm{df}=3, P=0.080$.

Table 4

Findings on the Relationships between Form of Training and Their Training Needs

\begin{tabular}{|c|c|c|c|c|}
\hline \multirow{2}{*}{$\begin{array}{l}\text { Opinion sought from } \\
\text { respondents }\end{array}$} & \multirow{2}{*}{$\begin{array}{l}\text { Respondents form of } \\
\text { training }\end{array}$} & \multicolumn{2}{|c|}{ Response $(N=250)$} & \multirow{2}{*}{$\begin{array}{l}\text { Pearson chi-square, df, and } \\
P \text {-value }\end{array}$} \\
\hline & & Yes & No & \\
\hline \multirow{3}{*}{$\begin{array}{l}\text { Would you need training in } \\
\text { mammals and plants to enhance } \\
\text { your performance }\end{array}$} & On job training & $73(86 \%)$ & $11(14 \%)$ & \multirow{3}{*}{$\chi^{2}=1.145, \mathrm{df}=3, P=0.766$} \\
\hline & College training & $92(83)$ & $19(17 \%)$ & \\
\hline & University training & $3(100 \%)$ & 0 & \\
\hline \multirow{3}{*}{$\begin{array}{l}\text { Would you need training in birds } \\
\text { and insects to enhance your } \\
\text { performance }\end{array}$} & On job training & $82(94 \%)$ & $6(6 \%)$ & \multirow{3}{*}{$\chi^{2}=0.633, \mathrm{df}=3, P=0.899$} \\
\hline & College training & $107(93 \%)$ & $9(7 \%)$ & \\
\hline & University training & $3(100 \%)$ & 0 & \\
\hline \multirow{3}{*}{$\begin{array}{l}\text { Would you need training in tour } \\
\text { planning and costing to enhance } \\
\text { your performance }\end{array}$} & On job training & $62(73 \%)$ & $24(27 \%)$ & \multirow{3}{*}{$\chi^{2}=6.767, \mathrm{df}=3, P=0.080$} \\
\hline & College training & $90(77 \%)$ & $27(23 \%)$ & \\
\hline & University training & $3(100 \%)$ & 0 & \\
\hline \multirow{3}{*}{$\begin{array}{l}\text { Would you need training in } \\
\text { culture and history to enhance } \\
\text { your performance }\end{array}$} & On job training & $71(85 \%)$ & $14(15 \%)$ & \multirow{3}{*}{$\chi^{2}=1.157, \mathrm{df}=3, P=0.763$} \\
\hline & College training & $88(81 \%)$ & $22(19 \%)$ & \\
\hline & University training & $3(100 \%)$ & 0 & \\
\hline \multirow{3}{*}{$\begin{array}{l}\text { Would you need training in } \\
\text { customers service and } \\
\text { communications skills to } \\
\text { enhance your performance }\end{array}$} & On job training & $73(86 \%)$ & $12(14 \%)$ & \multirow{3}{*}{$\chi^{2}=0.948, \mathrm{df}=3, P=0.814$} \\
\hline & College training & $97(85 \%)$ & $18(15 \%)$ & \\
\hline & University training & $3(100 \%)$ & & \\
\hline \multirow{3}{*}{$\begin{array}{l}\text { Would you need training in } \\
\text { reptiles and marine ecology to } \\
\text { enhance your performance }\end{array}$} & On job training & $75(85 \%)$ & $14(15 \%)$ & \multirow{3}{*}{$\chi^{2}=2.098, \mathrm{df}=3, P=0.552$} \\
\hline & College training & $102(89 \%)$ & $13(11 \%)$ & \\
\hline & University training & $4(100 \%)$ & 0 & \\
\hline \multirow{3}{*}{$\begin{array}{l}\text { Would you need you need } \\
\text { training in computer skills to } \\
\text { enhance your performance }\end{array}$} & On job training & $62(73 \%)$ & $24(27 \%)$ & \multirow{3}{*}{$\chi^{2}=1.590, \mathrm{df}=3, P=0.662$} \\
\hline & College training & $85(75 \%)$ & $29(25 \%)$ & \\
\hline & University training & $4(100 \%)$ & 0 & \\
\hline \multirow{3}{*}{$\begin{array}{l}\text { Would you need training in } \\
\text { eco-tourism to enhance your } \\
\text { performance }\end{array}$} & On job training & $71(84 \%)$ & $13(16 \%)$ & \multirow{3}{*}{$\chi^{2}=1.462, \mathrm{df}=3, P=0.691$} \\
\hline & College training & $97(83 \%)$ & $20(27 \%)$ & \\
\hline & University training & $3(100 \%)$ & 0 & \\
\hline \multirow{3}{*}{$\begin{array}{l}\text { Would you need training in } \\
\text { foreign language to enhance } \\
\text { your performance }\end{array}$} & On job training & $79(92 \%)$ & $7(8 \%)$ & \multirow{3}{*}{$\chi^{2}=8.479, \mathrm{df}=3, P=0.037$} \\
\hline & College training & $105(92 \%)$ & $10(8 \%)$ & \\
\hline & University training & $3(100 \%)$ & 0 & \\
\hline
\end{tabular}


Summary of H3. As can be seen from Table 4, all (100\%) the respondents who had been trained at university agreed that training on all the selected areas would make them perform better, followed by those trained formally in training colleges. Those trained on the job had the highest percentage of those who said training would not have much effect on their performance see training on mammals (14\%), tour planning (27\%), reptiles and ecology (15\%). As can be seen in Table 4, the finding was not significant at $\chi^{2}=8.479$, $\mathrm{df}=3$, $P=0.037$ (foreign language).

In this case, the study concluded that there was a weak relationship between the mode of training and the desire to be trained on birds and insects $\left(\chi^{2}=0.633\right.$, $\left.\mathrm{df}=3, P=0.899\right)$. We, therefore, fail to reject the null hypothesis that guides' opinion on their training needs is independent on how they were trained, on the job, formal or informal. All guides desired training.

\section{Findings of the Fourth Hypothesis (H4)}

The hypothesis investigated the effect of tour guide work experience on their training needs.

The study hypothesized that there is a significant relationship between the guides' work experience and their training needs. This hypothesis assumed that tour guides who have work experience of more than 10 years perform better than those who have been in the industry for less than five years. Only those guides who have not been exposed in the industry would require training.

H4: Ho: Tour guides' opinion on areas they require more training in order to improve their performance is independent of tour guide work experience.

$\mathrm{H}_{1}$ : Tour guides' opinion on areas they require more training in order to improve their performance is dependent on tour guide work experience.

The study hypothesized that guides with long work experience do not require training on mammal, bird reptiles and insects. With their many years of experience, they have already accumulated enough knowledge, skills and they do not desire more training to perform their guiding duties.

Once again, the study found that irrespective of the work experience, all guides desire to be trained in all selected areas. This finding is summarized in Table 5.

The study found that more than $85 \%$ of all respondents were of the opinion that training in all selected areas would enhance their performance. This opinion was shared by most guides irrespective of their work experience. A total of 221 (89\%) out of 250 respondents agreed that training on mammals and plants would enhance their performance. From this 191, 97\% respondents had work experience less than 5 years while $85 \%$ were 5 to 10 years, $78 \%$ with work experience from 10 to 15 years and only $84 \%$ (42) respondents had worked more than 15 years. However, this finding was not significant $\left(\chi^{2}=5.231\right.$, $\left.\mathrm{df}=3, P=0.156\right)$ as shown in Table 5.

On whether training on bird life and reptiles would enhance their performance, a total of $215(92 \%)$ respondents agreed with only $21(8 \%)$ disagreeing. From these 215 respondents, 29 of them had worked less than 5 years, while 78 respondents had worked between 5 to 10 years and 46 over 15 years. However, once again, the finding as can be seen in Table 5 was not significant with $\chi^{2}=1.759, \mathrm{df}=3, P=0.624$. 
Finally, the same question was asked but this time of training in tour planning and costing. A total of 171 respondents agreed. From these 171 respondents, 25 had worked less than 5 years, 64 respondents had worked between 5 to 10 years and 35 had more than 15 years' work experience. This finding was not significant as $\chi^{2}=3.999, \mathrm{df}=3, P=0.262$.

Table 5

Findings on the Relationship Between the Respondents'Work Experience and Their Opinion on Training Needs Information sought: Which of the following areas do you feel you need more training in order to improve your performance?

\begin{tabular}{|c|c|c|c|c|c|}
\hline \multirow{2}{*}{$\begin{array}{l}\text { Opinion sought from } \\
\text { respondents }\end{array}$} & \multirow{2}{*}{$\begin{array}{l}\text { Respondents' } \\
\text { work experience }\end{array}$} & \multicolumn{2}{|c|}{ Response $(N=250)$} & \multirow{2}{*}{$\begin{array}{l}\text { Chi-square goodness of fit, } \\
\text { df, and } P \text {-value }\end{array}$} & \multirow{2}{*}{$\begin{array}{l}\text { Pearson chi-square, } \\
\text { df, and } P \text {-value }\end{array}$} \\
\hline & & Yes & No & & \\
\hline \multirow{4}{*}{$\begin{array}{l}\text { Would training in } \\
\text { mammals and plants } \\
\text { enhance your } \\
\text { performance }\end{array}$} & Less than 5 years & $28(97 \%)$ & $1(3 \%)$ & \multirow{4}{*}{$\chi^{2}=104.018, \mathrm{df}=1, P<0.001$} & \multirow{4}{*}{$\chi^{2}=5.231, \mathrm{df}=3, P=0.156$} \\
\hline & $5-10$ years & $71(85 \%)$ & $13(15 \%)$ & & \\
\hline & $10-15$ years & $45(78 \%)$ & $12(22 \%)$ & & \\
\hline & Over 15 years & $42(84 \%)$ & $8(16 \%)$ & & \\
\hline \multirow{4}{*}{$\begin{array}{l}\text { Would training in } \\
\text { birds and insects } \\
\text { enhance your } \\
\text { performance }\end{array}$} & Less than 5 years & $29(97 \%)$ & $1(3 \%)$ & \multirow{4}{*}{$\chi^{2}=158.506, \mathrm{df}=1, P<0.001$} & \multirow{4}{*}{$\chi^{2}=1.759, \mathrm{df}=3, P=0.624$} \\
\hline & $5-10$ years & $78(90 \%)$ & $9(10 \%)$ & & \\
\hline & $10-15$ years & $58(94 \%)$ & $4(6 \%)$ & & \\
\hline & Over 15 years & $46(93 \%)$ & $4(7 \%)$ & & \\
\hline \multirow{4}{*}{$\begin{array}{l}\text { Would training in tour } \\
\text { planning and costing } \\
\text { enhance your } \\
\text { performance }\end{array}$} & Less than 5 years & $25(84 \%)$ & $5(16 \%)$ & \multirow{4}{*}{$\chi^{2}=49.846, \mathrm{df}=1, P<0.001$} & \multirow{4}{*}{$\chi^{2}=3.999, \mathrm{df}=3, P=0.262$} \\
\hline & $5-10$ years & $64(77 \%)$ & $20(23 \%)$ & & \\
\hline & $10-15$ years & $41(67 \%)$ & $21(37 \%)$ & & \\
\hline & Over 15 years & $35(69 \%)$ & $16(31 \%)$ & & \\
\hline \multirow{4}{*}{$\begin{array}{l}\text { Would training in } \\
\text { culture and history } \\
\text { enhance your } \\
\text { performance }\end{array}$} & Less than 5 years & $27(90 \%)$ & $3(10 \%)$ & \multirow{4}{*}{$\chi^{2}=90.084, \mathrm{df}=1, P<0.001$} & \multirow{4}{*}{$\chi^{2}=1.484, \mathrm{df}=3, P=0.686$} \\
\hline & $5-10$ years & $67(82 \%)$ & $15(18 \%)$ & & \\
\hline & $10-15$ years & $47(82 \%)$ & $11(18 \%)$ & & \\
\hline & Over 15 years & $40(80 \%)$ & $10(20 \%)$ & & \\
\hline \multirow{4}{*}{$\begin{array}{l}\text { Would training in } \\
\text { customers service and } \\
\text { communication skills } \\
\text { enhance your } \\
\text { performance }\end{array}$} & Less than 5 years & $29(97 \%)$ & $1(3 \%)$ & \multirow{4}{*}{$\chi^{2}=106.706, \mathrm{df}=1, P<0.001$} & \multirow{4}{*}{$\chi^{2}=4.115, \mathrm{df}=3, P=0.249$} \\
\hline & $5-10$ years & $70(83 \%)$ & $15(17 \%)$ & & \\
\hline & $10-15$ years & $45(82 \%)$ & $11(18 \%)$ & & \\
\hline & Over 15 years & $43(84 \%)$ & $8(16 \%)$ & & \\
\hline \multirow{4}{*}{$\begin{array}{l}\text { Would training in } \\
\text { reptiles and marine } \\
\text { ecology enhance your } \\
\text { performance }\end{array}$} & Less than 5 years & $39(94 \%)$ & $2(6 \%)$ & \multirow{4}{*}{$\chi^{2}=126.427, \mathrm{df}=1, P<0.001$} & \multirow{4}{*}{$\chi^{2}=1.462, \mathrm{df}=3, P=0.691$} \\
\hline & $5-10$ years & $72(87 \%)$ & $12(13 \%)$ & & \\
\hline & $10-15$ years & $53(86 \%)$ & $9(14 \%)$ & & \\
\hline & Over 15 years & $40(85 \%)$ & $7(15 \%)$ & & \\
\hline \multirow{4}{*}{$\begin{array}{l}\text { Would training in } \\
\text { computer skills } \\
\text { enhance your } \\
\text { performance }\end{array}$} & Less than 5 years & $27(87 \%)$ & $4(13 \%)$ & \multirow{4}{*}{$\chi^{2}=54.803, \mathrm{df}=1, P<0.001$} & \multirow{4}{*}{$\chi^{2}=4.238, \mathrm{df}=3, P=0.237$} \\
\hline & $5-10$ years & $64(75 \%)$ & $22(25 \%)$ & & \\
\hline & $10-15$ years & $41(70 \%)$ & $18(30 \%)$ & & \\
\hline & Over 15 years & $74(68 \%)$ & $16(32 \%)$ & & \\
\hline \multirow{4}{*}{$\begin{array}{l}\text { Would training in } \\
\text { eco-tourism enhance } \\
\text { your performance }\end{array}$} & Less than 5 years & $26(87 \%)$ & $4(13 \%)$ & & \\
\hline & $5-10$ years & $69(80 \%)$ & $17(20 \%)$ & $\gamma^{2}=108.502, \mathrm{df}=1, P<0.001$ & $\gamma^{2}=1.6$ \\
\hline & $10-15$ years & $50(84 \%)$ & $10(16 \%)$ & $x-100.002, \mathrm{d1}-1,5<0.001$ & $\chi-1.020, \mathrm{u1}-\mathrm{J}, \mathrm{r}-$ \\
\hline & Over 15 years & $44(88 \%)$ & $6(12 \%)$ & & \\
\hline in & Less than 5 years & $31(100 \%)$ & 0 & & \\
\hline foreign language & $5-10$ years & $73(90 \%)$ & $8(10 \%)$ & 00 & $=4.684 \mathrm{dt}=3, P=0$ \\
\hline enhance your & $10-15$ years & $58(92 \%)$ & $5(18 \%)$ & & \\
\hline performance & Over 15 years & $44(87 \%)$ & $7(13 \%)$ & & \\
\hline
\end{tabular}


Summary of H4. From the finding in Table 5, it can be seen that the majority of guides have less than 5 years of experience followed by those with 5 to 10 years of experience and finally those with more than 15 years of experience. As can be seen from Table 5, the majority of respondents (93\%) needed training on bird and insects $\left(\chi^{2}=1.759, \mathrm{df}=3, P=0.624\right)$ followed by foreign language (92\%) with the list being training in tour planning and costing $(73 \%)$ and computer skills $(73 \%)$. All the respondents below 5 years of experience said that training in at least one foreign language would enhance their performance $\left(\chi^{2}=4.684, \mathrm{df}=3, P=0.196\right)$.

From these observations, the study concluded that there was some relationship between tour guide work experience and their training needs. The majority of guides with less than 5 years of experience needed to be trained to enhance their performance. However, the relationship was not significant. We, therefore, failed to reject the hypothesis and conclude that tour guides' opinions of training needs are independent on their work experience.

\section{Discussion of Findings, Conclusions, and Recommendation}

This study found that the majority of guides in Kenya are males who are well educated and most of them have secondary school as the highest level of education. A few of them have been trained as guides while the majority have had on the job training. The majority of respondents are guides on contract or freelance while the minority are in permanent employment. This means that during the high seasons, the tourists and other visitors are in the hands of contracted guides. Some of these guides cannot afford to join a training institution to further their education neither are they trained by their employers.

This training gap affects their performance irrespective of their level of education and work experience. Academic qualifications are not considered when engaging these guides for a contract so there is no learning motivator since whatever level of education or work experience tour guides have, tour companies have a set amount of money they pay most of the guides. Guides on contract do not get the same salaries and statutory benefits of those on permanent employments making them disadvantaged and cannot afford to pay for their training since they only work for a few months during the high season.

This study confirms that tour guides in Kenya understand their strength and weaknesses in guiding skills and interpretation. It confirms that guides in Kenya irrespective of their education level professional qualification, work experience and terms of employment require more training on mammal, reptiles, the culture of East Africa, communication and computer skills in order to perform better and offer the customer better services and experiences.

Training of guides will likely increase their confidence when guiding and by extension improve their performance. This implies that training institutions and other stakeholders such as tour companies and professional association should include these areas as they develop their curriculum contents. The curriculum should take care of those guides with the primary and secondary level of education including university graduates. The study recommends that training is organized in modules and there should be training in different parts of the country targeting any guides as they interact with the visitors. From the success of a pilot training, then the programme can be rolled all over the country depending on the guide's need. Making the training available online will make it more manageable and may reach more guides who might be located in remote areas. Such programs should target guides at different levels and specialty offering all of them upward advancement in training. The issue that remains to be addressed is how and who will fund such program. The ministry of tourism, Kenya Association of Tour Operator and guiding professional association may meet and discuss sponsorship for guides training since most guides cannot afford. 
The study also observed that there was a very weak negative correlation between tour guide qualification and their opinion on their training needs, training on mammals and plants, culture and history, foreign language, reptiles and training on communication skills. From this finding, we can conclude that most of the guides have some professional training either formally or informally which may not be enough bearing in mind the emerging trend in customer behavior and changing needs.

Kenya is venturing into new source markets which bring about new cultures and visitors preferences. Guides have not been trained on how to manage challenges that come with this new consumer development and technological advancement. They may affect their performance and competitiveness of Kenya as a tourist destination. These challenges cannot be ignored by any tourism stakeholder be it accommodation providers, attractions providers and tour companies who package Kenya's tourism product. The government should have training policies that regulate guides training and also come up with sponsorship programs to train guides.

The findings mean that there is no significant relationship between tour guide professional qualification and their training needs. All guides irrespective of their qualification would like to be trained.

The findings confirmed that training need was independent of guides work experience. Thus, the study failed to reject the null hypothesis. This finding indicates that tour guides irrespective of the number of years they have worked in the tourism industry require more training in order to enhance their performance. As for the training institution, they should always plan to have some training for the guides during the low seasons. Such training will give them a forum where they can discuss with experts and fellow guides on the challenges they face. These training forums would help them confirm how correct the knowledge they have on wildlife, plants and people's culture is since most of them get information from different sources. Some guides indicated that they sometimes have conflicting information about attraction and mostly wildlife.

Training guides result in higher level of satisfaction making this finding important to operators and government agencies. This finding can be used to develop curriculum contents of guide training programs and continuing professional development. It can also be used to inform the guides training needs for those interested to develop such curriculum. Such curriculum should be consistent in terms of content, duration and certification bearing in mind the diversity and the complexity of guiding which may not allow the one-size-fits-all approach to training and education.

Any guides in Kenya do not have formal training and rely on what they learn on the job. They need regular programs in selected areas of their weakness as given in the study. The training material should also be available online for those guides who might not be available for full-time class attendance. Training should be a prerequisite to licensing for all guides to mitigate unethical guiding practices and poor performance which may damage the destination image. 
The study observed that most training institutions target students who have completed their primary and secondary schools studies. For those tour companies that offer on the job training the supervisors need to be receptive and supportive to the newly trained guides who have gained new ideas. Baseline data need to be collected to compare pre- and post-training performance. After completion of the studies, there was no evidence of any training institution that institution sought feedback from the industry on the performance of their graduates after employment.

\section{Implication of the Findings to the Tour Operators}

The study observes that most visitors in Kenya are interested in seeing the wildlife and mostly the big five (lions, leopards, elephants, rhinoceros, and buffaloes). Most of the guides confessed in the focus group discussion and interviews that they have limited knowledge of the other mammals thus affecting their performance. Tour operators should train the guides they hire on contract despite their terms of employment. Guides have limited knowledge of birds, reptiles, culture and computer skills and such training would enhance their performance.

\section{Implication of the Findings to the Policy Makers}

Tour guide training is very important before any person is licensed and allowed to work as a guide. The government should have a clear data bank on guides, their education and professional qualification and their specialization. This information is important if training will be organized and for forecasting. During the high seasons, most of the visitors are in the hands of unqualified guides since the demand of guides with a 4WD vehicle such as land cruises are few and are needed most when visiting the wet parks during the high season. This compromises the destination image and quality of services offered to the visitors. The study recommends further study on reasons while guiding career is male-dominated and its effect on the visitors. Further studies can be conducted to evaluate visitor's perception of the quality of services offered by guides and its effect on repeat visit and recommendation through word of mouth.

\section{Limitation of the Study}

The study used a combination of qualitative and quantitative research methods in collecting the data and analysis. For each of these methods, there were some noted limitations. For the quantitative method of data collection and analysis, it was not possible for the researcher to use probability method of sampling in selecting the respondents used in the study. This was because there is no clear cut list or sample frame for the population. To get the sample size used in the study, the study used a June 2017 TRA register which indicated that only 1,300 guides had renewed their license. Form this number, 305 was used as the sample size bearing in mind that the number kept changing as more guides renewed their license. After going to the field, the researcher realized that there were more guides that were guiding even though they had not renewed their license and therefore their names were missing. Others had not even registered with TRA at all. This means that the sample size may not have been a full representation of the population which was unknown.

The failure to use probability sampling method limits the ability to make a broader generalization from the finding. It was not possible to make statistical inference from the sample. 
For data collected using the qualitative method, cluster sampling method was used where each cluster was purposefully selected. These were the cluster that formed the FGDs and interviews of the key informants. In these FGDs, some had eight members while some have up to 20 participants where collecting individual's opinion was not possible. Some participants were patient until the end of the discussion while others gave their contribution and continued with their business. The study also observed that there were more professional associations than anticipated. To mitigate this limitation, a triangulation of the qualitative and quantitative methods was applied.

The data were collected in the high season when anybody whether a trained or licensed guide was in operations. Within this period, all categories of guides ranging from those in permanent employment term to those on contract were taking customers to the parks. The number of those respondents used is normally lower during the low season. This means that there might be a need to collect data during other seasons in order to compare the findings.

\section{References}

Ap, J., \& Wong, K. (2001). Case guide on tour guiding: Professionalism, issues and problem. Tourism Management, 22(5), 551-563.

Armstrong, M. (2009). A handbook of human resource management practice (11th ed.). London: Kogan Page Publishers.

Ballantyne, R., \& Hughes, K. (2001). Interpretation in ecotourism settings: Investigating tour guides' perceptions of their role, responsibilities and training needs. Journal of Tourism Studies, 12(2), 2-9.

Ballantyne, R., Packer, J., \& Hughes, K. (2009). Tourists' support for conservation messages and sustainable management practices in wildlife tourism experiences. Tourism Management, 30(5), 658-664.

Beardwell, I., Holden, L., \& Claydon, T. (2004). Human resource management: A contemporary approach (4th ed.). Harlow: Prentice Hall.

Black, R., \& Ham, S. (2005). Improving the quality of tour guiding: Towards a model for tour guide certification. Journal of Ecotourism, 4(3), 178-195.

Black, R., Ham, S., \& Weiler, B. (2001). Ecotour guide training in less developed countries: Some preliminary research findings. Journal of Sustainable Tourism, 9(2), 147-156.

Chan, A., \& Baum, T. G. (2004). The impact of tour guide performance on tourist satisfaction: A study of outbound tourism in Hong Kong. Proceedings of the Tourism, State of the Art II Conference (pp. 1-15), University of Strathclyde, Glasgow, June 27-30, 2004.

Chang, T., Kung, S. F., \& Luh, D. B. (2012). The innovative service model: A study on tour guide service design in Taiwan by ICT application. Journal of Academic Research International, 2(1), 192-198.

Cohen, E. (1982). Jungle guides in Northern Thailand: The dynamics of marginal occupational role. Sociological Review, 30(2), 234-266.

Cole, S. (1997). Anthropologists, local communities and sustainable development. In M. J. Stabler (Ed.), Tourism and sustainability: Principles to practice (pp. 219-230). Wallingford: CAB International.

Dahles, H. (2002). The politics of tour guiding: Image management in Indonesia. Annals of Tourism Research, 29(3), 783-800.

Dioko, L. A. N., \& Unakul, M. H. (2005). The need for specialized training in heritage tour guiding at Asia's world heritage sites - Preliminary findings on the challenges and opportunities. Paper presented at the 2005 PATA Educator's Forum, Macao.

Geva, A., \& Goldman, A. (1991). Satisfaction measurement in guided tours. Annual of Tourism Research, 18(2), 177-185.

Guest, D. E. (1997). Human resource management and industrial relations. Journal of Management Studies, 24(5), 503-521. 
Gurung, G., Simmons, D., \& Devlin, P. (1996). The evolving role of tourist guides: The Nepali experience. In R. Butler, \& T. Hinch (Eds.), Tourism and indigenous peoples (pp. 107-128). London: International Thomson Business Press.

Ham, S. H., \& Weiler, B. (2003). Toward a theory of quality in cruise-based interpretive guiding. Journal of Interpretation Research, 7(2), 29-49.

Hillman, W. (2004). Savannah guides: Ecotour guides of outback Australia. Proceedings of the Sociological Association of Australia 2004 Conference. From TASA 2004 Conference, December 8-11, 2004, Latrobe University, Beech Worth, VIC, Australia.

Holloway, J. (1981). The guided tour: A sociological approach. Annals of Tourism Research, 8(3), 377-402.

Hounnaklang, S. (2004). Profiles and roles of tour guides: A comparative study between Thailand and the UK. Paper presented at the 2nd Asia-Pacific CHRIE (Apac CHRIE) Conference and the 6th Biennial Conference on Tourism in Asia Proceedings, May 27-29, 2004, Phuket, Thailand.

Howard, J., Thwaites, R., \& Smith, B. (2001). Investigating the roles of the indigenous tour guide. Journal of Tourism Studies, 12(2), 32-39.

Kong, H., Cheung, C., \& Baum, T. (2009). Are tour guides in China ready for the booming tourism industry? Journal of China Tourism Research, 5(1), 65-76.

Lugosi, P., \& Bray, J. (2008). Tour guiding, organizational culture and learning: Lessons from an entrepreneurial tour company. International Journal of Tourism Research, 10(5), 467-479.

Mak, A. H. N., Wong, K. K. F., \& Chang, R. C. Y. (2011). Critical issues affecting the service quality and professionalism of the tour guides in Hong Kong and Macau. Tourism Management, 32(6), 1442-1452.

McDonnell, I. (2001). The role of the tour guide in transferring cultural understanding. Working Paper Series No. 3, University of Technology, Sydney, Australia.

Michie, M. (2004). Teaching science to indigenous students: Teacher as culture broker or is it something else? Paper presented at the Annual Meeting of the National Association for Research in Science Teaching, Vancouver, Canada, April 1-3, 2004.

Newstrom, W. J., \& Davis, K. (2002). Organizational behavior: Human behavior at work (11th ed.). McGraw-Hill/Irwin.

Nielsen, N. H. (2002). Job content evaluation techniques based on Marxian economics. WorldatWork Journal, 11(2), 52-62.

Ormsby, A., \& Mannle, K. (2006). Ecotourism benefits and the role of local guides at Masoala National Park, Madagascar. Journal of Sustainable Tourism, 14(3), 271-287.

Pereira, E. M., \& Mykletun, R. J. (2012). Guides as contributors to sustainable tourism? A case study from the Amazon. Scandinavian Journal of Hospitality and Tourism, 12(1), 74-94.

Pigors, P., \& Myers, A. C. (1989). Personnel administration: A point of view and method (9th ed.). New York, NY: McGraw-Hill Book Company.

Pond, K. (1993). The professional guide: Dynamics of tour guiding. New York, NY: Van Nostrand Reinhold.

Randall, C., \& Rollins, R. B. (2009). Visitor perceptions of the role of tour guides in natural areas. Journal of Sustainable Tourism, 17(3), 357-374.

Skanavis, C., \& Giannoulis, C. (2010). Improving the quality of ecotourism through advancing education \& training of Greek eco-tour guides: The role of training in environmental interpretation. Tourismos: An International Multidisciplinary Journal of Tourism, 5(2), 49-68.

Stevenson, A. (Ed.). (2010). Oxford dictionary of English. USA: Oxford University Press.

Swart, J., Mann, C., Brown, S., \& Price, A. (2005). Human resource development: Strategy and tactics. Oxford: Elsevier Butterworth-Heinemann Publications.

Wang, K. C., Hsieh, A. T., \& Huan, T. C. (2000). Critical service features in group package tour: An exploratory research. Tourism Management, 21, 177-189. 
Weiler, B., \& Black, R. (2015). The changing face of the tour guide: One-way communicator to choreographer to co-creator of the tourist experience. Tourism Recreation Research, 40(3), 364-378.

Weiler, B., \& Ham, S. H. (2001). Tour guides and interpretation. In D. Weaver (Ed.) Encyclopedia of ecotourism (pp. 549-563). Wallingford: CABI Publishing.

Weiler, B., \& Ham. S. H. (2002). Tour guide training: A model for sustainable capacity building in developing countries. Journal of Sustainable Tourism, 10(1), 52-69.

Wong, A. (2001). Satisfaction with local tour guides in Hong Kong. Pacific Tourism Review, 5(1), 59-67.

Yu, X., Weiler, B., \& Ham, S. (2001). Intercultural communication and mediation: A framework for analyzing the intercultural competence of Chinese tour guides. Journal of Vacation Marketing, 8(1), 75-87. 